Editorial-II

\title{
Need to have more Biomedical Journals with Impact Factor and importance of Publication Audit
}

\author{
Shaukat Ali Jawaid
}

How to cite this:

Jawaid SA. Need to have more Biomedical Journals with Impact Factor and importance of Publication Audit. Pak J Med Sci. 2019;35(4):882-886. doi: https://doi.org/10.12669/pjms.35.4.1300

This is an Open Access article distributed under the terms of the Creative Commons Attribution License (http://creativecommons.org/licenses/by/3.0), which permits unrestricted use, distribution, and reproduction in any medium, provided the original work is properly cited.

For the fourth consecutive year Pakistan Journal of Medical Sciences has retained the No. 1 position of having the highest Impact Factor among the biomedical journals published from Pakistan. In fact it has further improved and the current Impact Factor is 0.834 and the number of citations has also increased as compared to the previous year as per the Journal Citation Report released by the Clarivate Analytics from USA. The accompanying Table-1 also gives the details of Impact Factor of other journals from Pakistan covered by Clarivate Analytics and the number of citations. ${ }^{1}$ We are extremely grateful to the members of the Editorial
Board, International Advisors as well as our valued reviewers because we could achieve all this due to their devotion and dedication and it would not have been possible without their continued patronage, help, guidance and assistance which they have been extending in honorary capacity.

Impact Factor we have always believed is just one and not the only one criterion to judge the quality and standard of a medical journal ${ }^{2-3}$ We in Pakistan have about a dozen high quality peer reviewed biomedical journals but they could not get IF because till a few years ago most of these journals were being managed by non-professionals who

Table-I: Journals from Pakistan with Impact Factor (2018)

\begin{tabular}{llccc}
\hline Rank & Full Journal Title & $\begin{array}{c}\text { Total } \\
\text { Cites }\end{array}$ & $\begin{array}{c}\text { Journal } \\
\text { Impact Factor }\end{array}$ & $\begin{array}{c}\text { Eigen factor } \\
\text { Score }\end{array}$ \\
\hline 1 & PAKISTAN VETERINARY JOURNAL & 1,123 & 1.36 & 0.00127 \\
$\mathbf{2}$ & PAKISTAN JOURNAL OF MEDICAL SCIENCES & $\mathbf{2 , 0 9 5}$ & $\mathbf{0 . 8 3 4}$ & $\mathbf{0 . 0 0 3 6 8}$ \\
3 & INTERNATIONAL JOURNAL OF AGRICULTURE AND BIOLOGY & 2,793 & 0.802 & 0.00211 \\
4 & PAKISTAN JOURNAL OF ZOOLOGY & 1,621 & 0.79 & 0.00198 \\
5 & INTERNATIONAL JOURNAL OF PHARMACOLOGY & 840 & 0.754 & 0.00078 \\
6 & PAKISTAN JOURNAL OF BOTANY & 4,376 & 0.672 & 0.00264 \\
7 & JOURNAL OF THE PAKISTAN MEDICAL ASSOCIATION & 3,344 & 0.642 & 0.00317 \\
8 & PAKISTAN JOURNAL OF AGRICULTURAL SCIENCES & 869 & 0.618 & 0.00113 \\
9 & PAKISTAN JOURNAL OF PHARMACEUTICAL SCIENCES & 2,021 & 0.596 & 0.00258 \\
10 & JOURNAL OF ANIMAL AND PLANT SCIENCES & 1,620 & 0.529 & 0.00239 \\
11 & JCPSP-JOURNAL OF THE COLLEGE OF & 1,948 & 0.407 & 0.00187 \\
& PHYSICIANS AND SURGEONS PAKISTAN & & & \\
12 & JOURNAL OF THE CHEMICAL SOCIETY OF PAKISTAN & 896 & 0.393 & 0.00086 \\
\hline
\end{tabular}

Correspondence:

Shaukat Ali Jawaid

Chief Editor,

Pakistan Journal of Medical Sciences,

Karachi - Pakistan.

E-mail: pjms@pjms.org.pk did not know the importance of such indexations like IF. Now these journals are being edited by professionals, have applied and they hopefully will get the IF in the coming few years. It is taking time because the Clarivate Analytics has also made it a bit more difficult as now the new journals are first 
Table-II: Country wise submissions in PJMS during 2018

\begin{tabular}{|c|c|}
\hline Country & Total \\
\hline Algeria & 1 \\
\hline Argentine & 1 \\
\hline Aruba & 1 \\
\hline Australia & 2 \\
\hline Bahamas & 2 \\
\hline Bangladesh & 1 \\
\hline China & 308 \\
\hline Cyprus & 5 \\
\hline Ecuador & 1 \\
\hline Egypt & 12 \\
\hline Ghana & 1 \\
\hline India & 14 \\
\hline Indonesia & 26 \\
\hline Iran & 73 \\
\hline Iraq & 15 \\
\hline Italy & 1 \\
\hline Jordan & 1 \\
\hline Kazakhstan & 1 \\
\hline Korea & 15 \\
\hline Malaysia & 6 \\
\hline Nigeria & 5 \\
\hline Pakistan & 436 \\
\hline Palestine & 1 \\
\hline Romania & 1 \\
\hline Saudi Arabia & 98 \\
\hline Serbia & 1 \\
\hline South Africa & 2 \\
\hline Sudan & 1 \\
\hline Taiwan & 1 \\
\hline Thailand & 3 \\
\hline Turkey & 657 \\
\hline Turkmenistan & 1 \\
\hline United Arab Emirates & 5 \\
\hline United Kingdom & 7 \\
\hline United States & 5 \\
\hline Viet Nam & 4 \\
\hline Yemen & 1 \\
\hline Hungary & 1 \\
\hline Italy & 1 \\
\hline Belgium & 1 \\
\hline Grand Total & 1719 \\
\hline
\end{tabular}

covered in eSCIE (emerging Science Citation Index) for a few years, their publication and performance is monitored before they are shifted to SCIE and start getting Impact Factor and it can take from three to five years.

Even otherwise IF is being given too much importance by the regulatory authorities all over the world and Pakistan is no exception. However, if regulatory authorities overseas are
Table-III: City wise submissions from Pakistan during 2018 in PJMS

\begin{tabular}{|c|c|}
\hline City & Total \\
\hline Abbottabad & 1 \\
\hline Azad Kashmir & 4 \\
\hline Bahawalpur & 12 \\
\hline Bannu & 1 \\
\hline Chitral & 1 \\
\hline Dera Ghazi Khan & 1 \\
\hline Dera Ismail Khan & 2 \\
\hline Faisalabad & 17 \\
\hline Gilgit & 1 \\
\hline Gujranwala & 3 \\
\hline Gujrat & 1 \\
\hline Haripur & 3 \\
\hline Hyderabad/ Jamshoro & 8 \\
\hline Islamabad & 37 \\
\hline Karachi & 157 \\
\hline Kohat & 5 \\
\hline Lahore & 94 \\
\hline Larkana & 2 \\
\hline Lodhran & 1 \\
\hline Mansehra & 1 \\
\hline Mardan & 2 \\
\hline Mohmand District & 1 \\
\hline Multan & 4 \\
\hline Muzafarabad & 2 \\
\hline Nawabshah & 1 \\
\hline Peshawar & 40 \\
\hline Quetta & 4 \\
\hline Rahim Yar Khan & 2 \\
\hline Rawalpindi & 20 \\
\hline Saidu, KP & 1 \\
\hline Sargodha & 1 \\
\hline Sialkot & 3 \\
\hline Swat & 1 \\
\hline Wah Cantt. & 2 \\
\hline Grand Total & 436 \\
\hline
\end{tabular}

helping and encouraging the local journals to get indexed in important databases and earn IF, we do not see any such effort in Pakistan on the part of our regulatory agencies. Iran is just one example. Ever since the formation of Medical Journals Commission which has some professional editors as its members and is located at the Ministry of Health, the number of journals indexed in various databases and those enjoying Impact Factor has increased simply because they were helped and guided by the Commission. In Pakistan, we have two important regulatory bodies i.e. Pakistan Medical \& Dental Council (PM\&DC) and the Higher Education Commission (HEC). They do want more journals to enjoy Impact Factor and the HEC in particular has 
Table-IV: PJMS manuscripts statistics of 2018 at a Glance.

\begin{tabular}{lc}
\hline Published Articles: & $311(18 \%)$ \\
Rejected Articles: & $1211(70.5 \%)$ \\
Rejected article on similarity report: & $4(0.2 \%)$ \\
Withdraw Articles: & $17(1 \%)$ \\
Under Process: & $176(10.3 \%)$ \\
Received Articles: & $1719(100 \%)$ \\
\hline
\end{tabular}

made it mandatory for the faculty members in universities as well as those doing PhD to publish their research work in Impact Factor Journals but do not help journals acquire IF which can only be done through professional capacity building of the editors. After the reconstitution of the PM\&DC Journals Committee for which credit goes to Prof.Arshad Javed Vice Chancellor of Khyber Medical University and the former acting President of PM\&DC Mr. Justice Shakirullah Jan that it did start some training workshops for Editors. At least two such workshops were held at Khyber Medical University Peshawar and King Edward Medical University Lahore but then the new PM\&DC Council was nominated after the promulgation of the PM\&DC Ordinance 2018 and this training programme could not be continued for various reasons. The HEC also made somehalfhearted efforts to organize training for the Editors, exposing them to the working of Open Journal System (OJS) and the use of OJS by journals has also been made mandatory but the overall performance of both these regulatory bodies' remains sub-optimal. We have often highlighted as to what they are supposed to do to help the biomedical journals instead of just providing some financial grants as done by the HEC but without much success. ${ }^{2}$ We do need more biomedical journals with Impact Factor to help authors and relieve pressure on the three medical journals which enjoy Impact Factor. At present it has created a serious situation not only for the authors but also for the editors of IF journals that have to work under tremendous pressure, stress and strains because they cannot entertain beyond a particular number of manuscripts in view of their human resource as well as financial constraints. This naturally annoys a large number of authors whose manuscripts are not accepted for further processing while getting manuscript published in Impact Factor Journals overseas is very expensive which many authors from low income countries including Pakistan cannot afford. ${ }^{4-7}$

\section{PUBLICATION AUDIT}

We do Publication audit of Pakistan Journal of Medical Sciences annually. We believe it is a useful tool to evaluate progress of the journal and also plan for the future. ${ }^{8}$ A critical analysis for the year 2018 will reveal that Pakistan Journal of Medical Sciences attracted 1719 submissions from numerous countries. Table-II. Details of cities from where we received papers for publication during the same period from Pakistan are shown in Table-III. Out of this three hundred eleven papers (311) were published, 1211 were not accepted for further processing due to various reasons, four were rejected because of plagiarism, seventeen papers were withdrawn by the authors as they were impatient to get it published immediately

Table-V: Category Wise Manuscript Published in 2018 in PJMS

\begin{tabular}{|c|c|c|c|c|c|c|c|}
\hline Category & $\begin{array}{c}\text { Jan-Feb } \\
2018 \\
\end{array}$ & $\begin{array}{c}\text { Mar-Apr } \\
2018\end{array}$ & $\begin{array}{c}\text { May-Jun } \\
2018 \\
\end{array}$ & $\begin{array}{c}\text { Jul-Aug } \\
2018\end{array}$ & $\begin{array}{c}\text { Sep-Oct } \\
2018\end{array}$ & $\begin{array}{c}\text { Nov-Dec } \\
2018\end{array}$ & Total \\
\hline Original Articles & 44 & 46 & 41 & 43 & 45 & 47 & 266 \\
\hline Case Reports & 1 & 3 & 3 & 3 & 1 & 2 & 13 \\
\hline Short Communication & & & 2 & 1 & 1 & 2 & 6 \\
\hline Editorial & 1 & & & 1 & 1 & 1 & 4 \\
\hline Review Article & & 2 & 1 & & & 1 & 4 \\
\hline View Point & 1 & & 1 & & 1 & 1 & 4 \\
\hline Conference Proceedings & & 1 & & 1 & 1 & & 3 \\
\hline Correspondence & & & 1 & 1 & 1 & & 3 \\
\hline Leading Article & & & 1 & & 1 & & 2 \\
\hline Systematic Review & & & 1 & 1 & & & 2 \\
\hline Clinical Case Series & & & & 1 & & & 1 \\
\hline Guest Editorial & 1 & & & & & & 1 \\
\hline Workshop Proceedings & & & & 1 & & & 1 \\
\hline Retraction & 1 & & & & & & 1 \\
\hline Grand Total & 49 & 52 & 51 & 53 & 52 & 54 & 311 \\
\hline
\end{tabular}


Table-VI: Country Wise Manuscript Published in 2018 in PJMS

\begin{tabular}{|c|c|c|c|c|c|c|c|}
\hline Category & $\begin{array}{c}\text { Jan-Feb } \\
2018 \\
\end{array}$ & $\begin{array}{c}\text { Mar-Apr } \\
2018\end{array}$ & $\begin{array}{c}\text { May-Jun } \\
2018 \\
\end{array}$ & $\begin{array}{c}\text { Jul-Aug } \\
2018\end{array}$ & $\begin{array}{c}\text { Sep-Oct } \\
2018 \\
\end{array}$ & $\begin{array}{c}\text { Nov-Dec } \\
2018 \\
\end{array}$ & Total \\
\hline Pakistan & 26 & 28 & 20 & 21 & 25 & 30 & 150 \\
\hline Turkey & 10 & 14 & 17 & 11 & 7 & 13 & 72 \\
\hline China & 10 & 3 & 6 & 8 & 11 & 5 & 43 \\
\hline Saudi Arabia & 2 & 4 & 4 & 7 & 5 & 2 & 24 \\
\hline Iran & & & & 2 & & 1 & 3 \\
\hline Cyprus & & 1 & & 1 & 1 & & 3 \\
\hline Iraq & & & & & 1 & 1 & 2 \\
\hline Korea & & & & 2 & & & 2 \\
\hline United Arab Emirates & & 2 & & & & & 2 \\
\hline Thailand & 1 & & & & & 1 & 2 \\
\hline Malaysia & & & & 1 & & & 1 \\
\hline Bangladesh & & & & & & 1 & 1 \\
\hline India & & & & & 1 & & 1 \\
\hline United Kingdom & & & 1 & & & & 1 \\
\hline Romania & & & 1 & & & & 1 \\
\hline Australia & & & 1 & & & & 1 \\
\hline Serbia and Montenegro & & & 1 & & & & 1 \\
\hline UAE & & & & & 1 & & 1 \\
\hline Grand Total & 49 & 52 & 51 & 53 & 52 & 54 & 311 \\
\hline
\end{tabular}

and we could not accommodate them. In some cases if the topic of the study was interesting, the write up was good and did add some useful information to the medical literature but the similarity index score was a bit high after checking with iThenticate, they were asked to revise it, reduce the similarity index score to the acceptable limits before the paper was accepted for further processing as we try to practice an author friendly policy. Table-IV.

As usual highest number of submissions during 2018 was received from Turkey (657) as against 508 during 2017. Submissions from Pakistan during 2018 were (436) as against (453) during the last year which shows a decrease simply because we continue to raise the standard bar every year as the number of submissions increases. Submissions from China during 2018 were (308) as against (331) during 2017. Submissions from Iran were one hundred three which increased from 73 in 2017. We have seen a progressive increase in the number of submissions from Saudi Arabia 98 in 2018 from 62 in 2017. Table-II.

Submissions from within the country were highest from Karachi 157 followed by Lahore 94, Peshawar 40, Islamabad 37, Rawalpindi 20, Faisalabad 17 and Bahawalpur 12. Table-III. This also reflects more academic activity and interest in research, medical writing in these major cities as per submissions that we have received. In fact a large number of submissions from most of the cities are accommodated by other biomedical journals which are not so stringent with the peer review system and quality control, as such it is not possible to have exact status of interest in research and Publications among the healthcare professionals affiliated with various medical institutions all over the country.

The number of papers published from Pakistan during 2018 was 311 and as expected most of them were original articles (266) followed by Case Reports (13), Short Communications (6) Editorials, Review articles and Viewpoints four each. Most of the issues published during 2018 had between 49 to 54 manuscripts. Table-V. If we look at country wise distribution of manuscripts published during 2018, highest number were from Pakistan (150) followed by Turkey (72), China (43) and Saudi Arabia (24) Table-VI. Overall we have made further progress in attracting quality manuscripts not only from Pakistan but also from overseas. However, still there are numerous hurdles to cross and trying to maintain and further improve the standard is not going to be an easy task particularly in view of the tremendous increase in cost of production due to devaluation of the Pakistani currency and appreciation in the value of US dollar as we have to pay in foreign exchange for most of the services that we have acquired from overseas i.e. iThenticate for plagiarism check, CrossRef 
and CrossCheck for Digital Object Identified (DOI), preparation of XML files for submission to PubMed Central to be visible on the PubMed. Constant efforts will be needed to overcome some of these problems for which we expect the help and assistance of the members of the Editorial Board, our valued Reviewers and some understanding on the part of authors. If authors are a bit careful, read and follow instructions for authors on the website of the journal to which they wish to submit their manuscript, it will not only minimize trauma to their manuscripts but will also make the life of the editors a bit comfortable. ${ }^{9}$

The authors also need to clear some of their misconceptions. It is a well-known fact that "Gift Authorship" is very common in many countries including Pakistan and every effort needs to be made to check this menace. PM\&DC has now decided to give equal credit to six authors in a manuscript but this does not mean that every manuscript can have six authors. There is a clearly laid down criteria for authorship by International Committee of Medical Journal Editors (ICMJE) and most good quality peer review journals follow this with little bit of modification. ${ }^{10}$ Hence, those submitting the manuscripts have to be very careful as regards authorship and enlist only those as authors who are eligible for authorship otherwise they risk their manuscripts being rejected from most reputed peer reviewed biomedical journals. ${ }^{11}$

During 2018, we received seventy eighty requests from authors for fast track processing of their manuscripts, a facility which is available in a very few selected cases i.e. if the main author has to appear in CPSP Fellowship Examination or defense of PhD Thesis. Only fifteen such genuine requests were entertained. It is the quality of the manuscript which decides the time frame of its further processing and publications as every editor is keen to publish good quality manuscripts which also have better chances of further citations as it will help the journal to improve its Impact Factor.

\section{REFERENCES}

1. InCites Journal Citation Report by Clarivate Analytics 2018.

2. Jawaid SA. Despite misuse and abuse, Journal Impact Factor will retain its impact and won't fade away soon. (Editorial) JPMI Peshawar. 2014;28(1):1-4.

3. Jawaid SA, Jawaid M. Impact of Impact Factor, Publication Audit and the importance of Citations. Pak J Med Sci. 2016; 32(4):797-800. Doi: http://dx.doi.org/10.12669/ pjms.324.10927

4. Jawaid SA. Improving standard of medical journalism in Pakistan: A welcome initiative by the PM\&DC. (Editorial) Pak J Med Sci. 2004; 20(1):5-8.

5. Jawaid SA. Professionalism in Medical Journalism and Role of HEC, PM\&DC. Annals of King Ed Med Univ. 2016; 22(3):164-166.

6. Jawaid SA, Jawaid M. What regulatory agencies like HEC, PM\&DC can do to help improve quality and standard of Pakistani Biomedical Journals. Pak J Med Sci. 2017;33(2):251253. Doi: https://doi.org/10.12669/pjms.332.12857

7. Jawaid SA. Training of Medical editors and the role of Professional organizations. In: Proceeding of First National Conference on Medical Editing. Eds. Jawaid SA, Jafary MH, Aslam M. Published by Pakistan Medical Journalists Association Karachi - Pakistan 2007.

8. Jawaid SA. Publication Audit - a useful tool to evaluate progress and plan for the future. Pak J Med Sci 2015;31(2):490492. Doi: http://dx.doi.org/10.12669/pjms.312.7682

9. Jawaid SA, Jawaid M. Author's failure to read and follow instructions leads to increased trauma to their manuscripts. Pak J Med Sci. 2018; 34(3):519-524. Doi: https://doi. org/10.12669/pjms.343.15633

10. http://www.icmje.org/recommendations/browse/rolesand-responsibilities / defining-the-role-of-authors-andcontributors.html Accessed on July 1, 2019

11. Jawaid SA, Jawaid M. Common reasons for not accepting manuscripts for further processing after editor's triage and initial screening. Pak J Med Sci. 2019; 35(1):1-3. Doi: https:// doi.org/10.12669/ pjms.35.1.28 